\title{
APLIKASI PERTIMBANGAN WISATA DI PULAU LOMBOK DENGAN METODE FUZZY MAMDANI \& ALGORITMA GENETIKA
}

\author{
Zanul Harir ${ }^{1}$, Ida Bagus Ketut Widiartha*2, Royana Afwani ${ }^{3}$ \\ ${ }^{1,2,3}$ Program Studi Teknik Informatika, Universitas Mataram \\ Email: ${ }^{2}$ zanul17@gmail.com, ${ }^{2}$ widi@unram.ac.id, ${ }^{3}$ royana@unram.ac.id \\ *Penulis Korespondensi
}

(Naskah masuk: 30 Oktober 2018, diterima untuk diterbitkan: 26 November 2020)

\begin{abstract}
Abstrak
Pulau Lombok memiliki pariwisata berupa keindahan alam dan kebudayaan yang menarik, sehingga juga mendapat tiga penghargaan pada World Halal Tourism Awards 2016 dengan faktor pertumbuhan kunjungan wisatawan sebesar $13 \%$ pada tahun tersebut. Adanya sebuah aplikasi yang dapat membantu wisatawan dalam menentukan keputusan perjalanan wisata mereka adalah wajib. Aplikasi ini dikembangkan dengan logika Fuzzy Mamdani dan Algoritma Genetika dengan tujuan memberikan rekomendasi pariwisata.

Logika Fuzzy Mamdani memberikan pertimbangan wisata berdasarkan 5 parameter (anggaran, rencana perjalanan, akomodasi, makanan dan minuman, serta biaya transportasi) yang kemudian menjadi 5 fungsi keanggotaan untuk membangun kombinasi aturan pada fuzzy dan menghasilkan keluaran berupa pertimbangan wisata, yaitu: Tidak Memungkinkan, Cukup Memungkinkan, dan Memungkinkan. Kombinasi lima fungsi keanggotaan tersebut, menghasilkan 10.080 aturan, yang digunakan untuk mengetahui seseorang memungkinkan, atau tidak untuk berwisata ke pulau Lombok dengan constrain parameter yang dimiliki, yang dibangkitkan dengan menggunakan fungsi Defuzzifikasi Mean of Max (MOM). Algortima Genetika digunakan dalam memberikan alokasi penggunaan budget yang optimal dalam berwisata di Pulau Lombok.

Hasil pengujian dengan perhitungan manual dan model defuzzifikasi yang berbeda memiliki akurasi 100\%. Untuk implementasi Algoritma Genetika, aplikasi memperoleh alokasi anggaran optimal pada probabilitas crossover (pc) dan probabilitas mutasi (pm) dengan (pc) 0,7 dan (pm) 0,2.
\end{abstract}

Kata kunci: Pariwisata, logika fuzzy, FIS Mamdani, algoritma genetika

\section{TOURISM CONSIDERATION APPLICATION IN LOMBOK ISLAND WITH FUZZY MAMDANI METHOD AND GENETIC ALGORITHM}

\begin{abstract}
Tourism in Lombok has an interesting culture, it makes Lombok got three awards at the 2016 World Halal Tourism Awards and became a growth factor for tourist visits by 13\% that year. An application that can help tourists in determining travel decision is mandatory.

The application developed with Mamdani Fuzzy Logic and Genetic Algorithm to provide tourism recommendations. The Fuzzy Mamdani Logic Method provides tourism considerations based on 5 parameters (budget, travel plans, accommodation, food and drinks, and transportation costs) which then become 5 membership functions to build a combination of rules on fuzzy and produce output in the form of tourism's considerations: Not Enable, Enough Enable, and Enable. The combination of the 5 membership functions constructed 10.080 fuzzy rules, that's used to know wheater tourists enables them to go to Lombok with the limitation that they have. The defuzzification used is the Mean of Max (MOM). Genetic Algorithm (GA) is used in providing optimal budget allocation in traveling on Lombok Island

The results of testing with manual calculations and different defuzzification models have 100\% accurate, the application of GA obtained optimal budget allocation on crossover probability (pc) and mutation probability (pm) combination with ( $p c) 0.7$ and (pm) 0.2 .
\end{abstract}

Keywords: Tourism, Fuzzy Logic, FIS Mamdani, Genetic.

\section{PENDAHULUAN}

Sektor pariwisata merupakan salah satu industri yang sangat potensial bagi Indonesia khususnya
Pulau Lombok yang memiliki keindahan alam dan kebudayaan menarik. Pada tahun 2016, Pulau Lombok mendapat tiga penghargaan dalam ajang 
World Halal Tourism Awards (WHTA) dan hal tersebut menjadi daya tarik bagi para wisatawan sehingga pertumbuhan kunjungan wisatawan di Pulau Lombok mencapai 13\% dari tahun 2016 ke 2017 (Dinas Pariwisata NTB dan Badan Pusat Statistik NTB).

Meningkatnya jumlah wisatawan di pulau Lombok seharusnya diikuti dengan tersedianya fasilitas/sistem yang dapat memberikan manfaat secara spesifik dalam membantu wisatawan menentukan keputusan selama berwisata di Pulau Lombok sesuai dengan kebutuhan dan anggaran (budget) yang dimilikinya. Dengan fasilitas tersebut, diharapkan para wisatawan dapat merencanakan perjalanan wisatanya dengan baik dan dapat mendorong mereka untuk berwisata ke Pulau Lombok.

Budget adalah komponen penting dalam menjamin kenyamanan wisatawan, karena segala kebutuhan wisatawan saat berwisata di suatu tempat membutuhkan uang. Agar budget yang dimiliki wisatawan dapat digunakan dengan optimal, maka perlu diketahui selot-selot dana yang harus disiapkan dalam berwisata. Berdasarkan data kuesioner yang didapatkan dari 100 orang responden/wisatawan di Pulau Lombok terkait pola pengeluaran anggaran mereka yaitu $100 \%$ memilih pengeluaran untuk akomodasi, makanan minuman, dan transportasi. Sedangkan $38 \%$ memilih pengeluaran belanja, $30 \%$ memilih pengeluaran hiburan, $31 \%$ memilih pengeluaran untuk pemandu wisata, dan $17 \%$ memilih lainnya. Berdasarkan data tersebut maka jenis pengeluaran yang wajib dikeluarkan oleh seorang wisatawan di Pulau Lombok adalah akomodasi (tempat untuk beristirahat sesuai dengan kebutuhan primer manusia), makanan dan minuman (sudah menjadi kebutuhan primer manusia), serta transportasi yang akan digunakan untuk mengunjungi sebuah objek wisata.

Dalam penelitian ini digunakan Logika Fuzzy untuk memberikan pertimbangan wisata karena metode ini sangat kuat untuk menyelesaikan permasalahan dalam lingkungan yang tidak pasti/ambigu (Maslim, 2013), selain itu dalam teori logika Fuzzy sebuah nilai bisa bernilai benar dan salah secara bersamaan namun berapa besar kebenaran dan kesalahan suatu nilai tergantung kepada bobot keanggotaan yang dimilikinya (Solikin, 2011). Model Fuzzy Mamdani dipilih karena memiliki proses perhitungan yang lebih terperinci dan hasil perhitungan lebih akurat (Ismaya, 2016).

Algoritma Genetika adalah jenis evolutionary algorithms, yang berarti bahwa algoritma genetika merupakan suatu teknik optimasi yang didasarkan pada algoritma genetika alami yang mirip dengan evolusi mahluk hidup dalam menghasilkan suatu solusi yang optimal (Arinanta, 2017). Algoritma ini digunakan untuk menghitung alokasi penggunaan anggaran yang optimal karena Algoritma ini dapat menirukan proses evolusi makhluk hidup (algoritma alamiah) (Ayuningtias, 2017) dalam menyelesaikan suatu permasalahan yang memiliki banyak kemungkinan solusi dengan baik(Widodo, 2010)

Berdasarkan masalah ataupun kebutuhan pada bidang wisata di pulau Lombok, dan juga literatur yang dijadikan referensi maka penelitian ini mengimplementasikan metode Logika Fuzzy Mamdani dalam memberikan pertimbangan wisata berdasarkan 5 parameter (budget, lama wisata, harga akomodasi/hotel, makanan dan minuman, serta transportasi) dan menghasilkan keluaran berupa pertimbangan wisata : Tidak Memungkinkan, Cukup Memungkinkan, dan Memungkinkan. Selain itu juga menggunakan Algortima Genetika dalam memberikan alokasi penggunaan budget yang optimal dalam berwisata di Pulau Lombok. Aplikasi ini diharapkan mampu memberikan informasi pertimbangan wisata yang spesifik kepada wisatawan yang ingin berwisata ke Pulau Lombok sesuai dengan kebutuhan dan jumlah budget yang dimiliki wisatawan

\section{METODE PENELITIAN}

Metode pembuatan aplikasi pertimbangan berwisata di Pulau Lombok dengan metode Logika Fuzzy Mamdani dan Algoritma Genetika terdiri dari beberapa tahapan yaitu studi literatur, analisis kebutuhan aplikasi, pengumpulan data, perancangan aplikasi, implementasi atau pembangunan aplikasi, pengujian aplikasi, dan apabila aplikasi telah dianggap sesuai akan diakhiri dengan dokumentasi aplikasi.

Pada tahap studi literatur dilakukan pembelajaran untuk memahami topik yang berkaitan dengan metode logika fuzzy dan algoritma genetika dengan mencari materi penunjang dari buku, jurnal ilmiah, dan lainnya yang berkaitan dengan kedua metode tersebut sesuai dengan aplikasi yang akan dikembangkan.

Pada tahap analisa kebutuhan aplikasi dilakukan pendefinisian terhadap kebutuhan data-data penelitian serta penggunaan teknik, metode, atau model untuk menyelesaikan permasalahan terhadap aplikasi yang akan dibuat. Data-data yang dibutuhkan dalam penelitian ini adalah data objek wisata di Pulau Lombok. Serta metode yang digunakan untuk menyelesaikan permasalahan aplikasi adalah Logika Fuzzy Mamdani dan Algoritma Genetika.

Setelah melakukan analisa terhadap kebutuhan aplikasi, maka tahap selanjutnya adalah melakukan pengumpulan data yang dibutuhkan. Dalam penelitian ini, data objek wisata didapatkan berdasarkan peraturan daerah provinsi Nusa Tenggara Barat (NTB) Nomor 7 Tahun 2013 tentang Kawasan Strategis Pariwisata Daerah (KSPD). Bahan atau data yang dibutuhkan dalam pembangunan aplikasi pertimbangan berwisata di Pulau Lombok dengan metode Logika Fuzzy Mamdani dan Algoritma Genetika meliputi: 
1. Data hotel dari website Traveloka dengan batasan harga sewa dari Rp 100.000 - Rp 1.000 .000 untuk satu malam per tanggal 10 Januari 2018.

2. Data Kawasan Strategis Pariwisata Daerah (KSPD) berdasarkan peraturan daerah provinsi NTB Nomor 7 Tahun 2013.

Setelah pengumpulan data dilakukan perancangan sistem atau aplikasi dengan membuat usecase diagram yang menggambarkan bagaimana user akan berinteraksi dengan aplikasi. Selain itu akan digambarkan arsitektur aplikasi untuk menggambarkan alur aplikasi yang akan dibuat dengan mengimplementasikan logika fuzzy mamdani dan algoritma genetika.

Tahap selanjutnya yaitu Implementasi aplikasi yang merupakan tahap untuk mengimplementasikan seluruh tahapan yang telah dilakukan sebelumnya dalam tahap desain dan rancangan aplikasi ke dalam bahasa program.

Setelah implementasi dilakukan pengujian terhadap aplikasi yang dibuat. pengujian yang dilakukan antara lain :

1. Pengujian Logika Fuzzy Mamdani.

Pengujian perhitungan manual dengan perhitungan yang dilakukan oleh aplikasi. Selain itu dilakukan pengujian perhitungan defuzzifikasi Mean of Max (MOM) dengan centroid untuk melihat perbedaan hasil nilai fuzzy dan kesimpulan yang dihasilkan. Untuk perhitungan dengan defuzzifikasi centroid menggunakan aplikasi MATLAB dengan model fungsi keanggotaan yang sama dengan aplikasi.

\section{Pengujian Algoritma Genetika}

Pengujian untuk mendapatkan nilai pc dan pm terbaik dengan jumlah generasi maksimal sebanyak $\mathrm{N}$ generasi. Nilai pc dan pm yang digunakan dalam skenario uji coba adalah berdasarkan referensi dari Mahmudi [16] yang menyatakan bahwa menentukan pc dan pm tidak mudah, namun biasanya nilai pc yang digunakan antara 0.3-0.8 dan nilai $\mathrm{pm}<0.5$.

\section{PERANCANGAN APLIKASI}

Gambar 1 merupakan use case diagram sistem aplikasi pertimbangan berwisata di Pulau Lombok. Aplikasi yang akan dirancang terdiri dari satu orang aktor yaitu wisatawan. Wisatawan dapat melakukan konsultasi pertimbangan wisata dengan memasukkan parameter-parameter yang telah ditentukan. Setelah melakukan konsultasi wisatawan dapat melihat hasil konsultasi mengenai pertimbangan wisata, melihat alokasi pertimbangan budget, serta dapat melihat rekomendasi hotel dengan detail hotel seperti nama, harga sewa, dan alamat hotel.

\subsection{Arsitektur Aplikasi}

Arsitektur aplikasi menunjukkan alur kerja dari aplikasi yang dibuat dan hubungan antar prosesproses yang ada pada aplikasi yang dibuat. Gambar 2 menunjukkan arsitektur dari aplikasi Pertimbangan
Wisata di Pulau Lombok dengan Metode Fuzzy Mamdani dan Algortma Genetika.

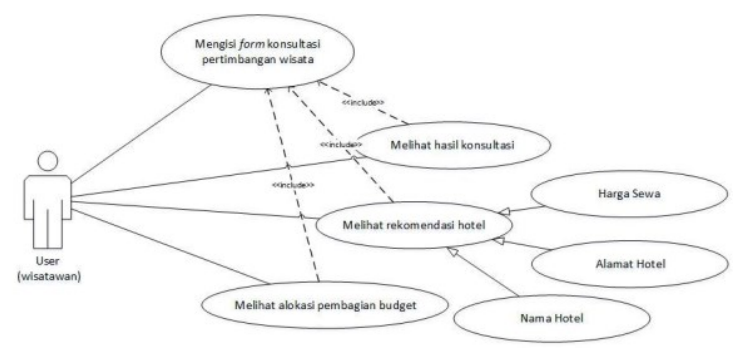

Gambar 1. Usecase aplikasi

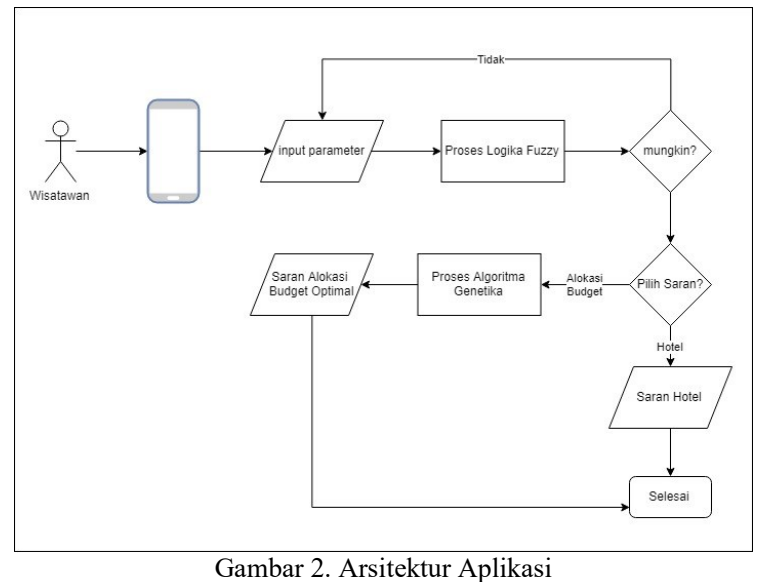

Sesuai dengan Gambar 2, wisatawan menggunakan smartphone-nya (handphone) membuka aplikasi Pertimbangan Wisata di Pulau Lombok dengan Metode Fuzzy Mamdani dan Algortma Genetika. Kemudian wisatawannya memasukkan (input) 5 parameter sesuai yang dijelaskan pada section Pendahuluan yaitu budget, lama wisata, harga akomodasi, makanan dan minuman, serta transportasi yang wisatawan inginkan. Setelah itu input-an akan diproses menggunakan Logika Fuzzy Mamdani untuk mendapatkan pertimbangan wisata. Jika pertimbangan wisata Tidak Memungkinkan maka wisatawan akan dialihkan kembali ke proses input. Jika pertimbangan wisata Cukup atau Memungkinkan maka wisatawan akan memilih saran Hotel dan Alokasi Penggunaan Budget. Saran hotel yang diberikan sesuai dengan masukan harga hotel. Daftar hotel diambil dari web traveloka.com untuk harga hotel antara Rp. 100.000 - Rp 1. 000.000 . Untuk saran budget diproses menggunakan Algoritma Genetika.

\subsection{Fuzzy Mamdani}

Terdapat beberapa istilah penting yang harus dipahami dalam logika fuzzy diantaranya adalah variabel, himpunan, semesta pembicaraan, dan domain. Variable fuzzy adalah sesuatu yang akan dibahas dalam suatu sistem fuzzy seperti umur, temperatur, dan permintaan barang. Sedangkan himpunan fuzzy merupakan suatu grup yang mewakili suatu kondisi dalam variable seperti muda, parobaya, 
dan tua pada variabel umur. Kemudian semesta pembicaraan adalah nilai yang diperbolehkan untuk dioperasikan dalam variabel fuzzy serta domain adalah nilai yang diizinkan dalam semesta pembicaraan dan boleh dioperasikan dalam himpunan fuzzy (Sukandy, 2014). Sementara itu, Metode Fuzzy Mamdani sering dikenal dengan nama metode Min-Max. Metode ini diperkenalkan oleh Ebrahim Mamdani pada tahun 1975 (Arifin, 2015). Proses pertama pada metode logika fuzzy adalah fuzzifikasi, yaitu proses pemetaan input kedalam nilai fuzzy dengan fungsi keanggotaan. Kemudian proses kedua Implikasi, yaitu proses penarikan kesimpulan dari IF-THEN rule, dalam metode Mamdani penarikan kesimpulan menggunakan fungsi implikasi MIN. Apabila sistem terdiri dari beberapa aturan, maka inferensi diperoleh dari gabungan antar aturan, proses ini disebut agregasi. Proses terakhir adalah defuzzifikasi, yaitu proses penegasan bilangan fuzzy menjadi bilangan crisp (tegas). Defuzzifikasi dengan metode Mean of Max (MOM) dilakukan dengan mengambil nilai rata-rata domain yang memiliki keanggotaan maksimum.

Terdapat enam langkah dalam menentukan pertimbangan berwisata di Pulau Lombok, Gambar 3 menunjukkan diagram alir dalam menentukan pertimbangan berwisata di Pulau Lombok dengan metode fuzzy Mamdani.

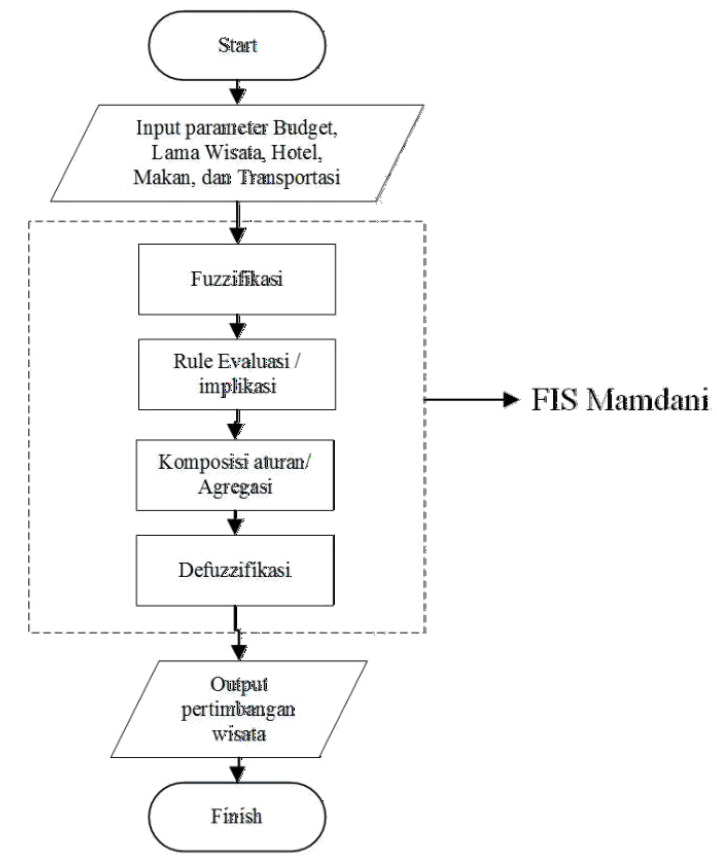

Gambar 3. Diagram alir FIS Mamdani

Langkah-langkah berikut merupakan contoh perhitungan aplikasi dalam memberikan pertimbangan wisata dengan metode Fuzzy Mamdani. Skenario perhitungan ini menggunakan input budget sebesar Rp 1.650.000, lama wisata selama 3 hari, perkiraan harga akomodasi Rp 181.500, makan Rp 165.000, dan transportasi Rp 145.500 :

\subsubsection{Fuzzifikasi}

Untuk mendapatkan nilai keanggotaan fuzzy dari lima variabel input budget, lama wisata, akomodasi/hotel, makanan dan minuman, serta transportasi digunakan fungsi keanggotaan. Fungsi keanggotaan dibuat berdasarkan data kuesioner dari 100 orang responden/wisatawan di Lombok. Penyebaran kuesioner dilakukan pada tanggal 1-28 Juli 2018 bertempat di beberapa objek wisata di semua KSPD di Lombok sesuai perda provinsi NTB Nomor 7 Tahun 2013. Item-item berikut merupakan fungsi keanggotaan yang terbentuk :

a) Budget

Berikut merupakan distribusi frekuensi jumlah budget yang dibawa oleh wisatawan berdasarkan data kuesioner dari 100 orang responden/wisatawan di Lombok.

\begin{tabular}{clll}
\multicolumn{3}{c}{ Tabel 1. Distribusi frekuensi budget wisatawan di Pulau Lombok } \\
\hline No & Range Budget & $\begin{array}{l}\text { Freku- } \\
\text { ensi }\end{array}$ & $\begin{array}{l}\text { Presen- } \\
\text { tase (\%) }\end{array}$ \\
\hline 1 & $<$ Rp 1,000,000 & 0 & $0 \%$ \\
2 & Rp 1,000,000 - Rp 5,000,000 & 74 & $74 \%$ \\
3 & Rp 5,000,000 - Rp 9,000,000 & 21 & $21 \%$ \\
4 & Rp 9,000,000 - Rp 13,000,000 & 5 & $5 \%$ \\
5 & $>=$ Rp 13,000,000 & 0 & $0 \%$ \\
& $\quad$ Total & $\mathbf{1 0 0}$ & $\mathbf{1 0 0 \%}$ \\
& Rata-Rata Budget & Rp 3,860,825 \\
\hline
\end{tabular}

Dari tabel 1 dapat dilihat bahwa frekuensi jumlah budget terbanyak terdapat pada range antara 1 juta sampai 5 juta, hal tersebut sesuai dengan nilai ratarata yang dihitung dari data keseluruhan yaitu 3.860.000 (dibulatkan) berada pada range tersebut. Fungsi keanggotaan budget kemudian dibentuk berdasarkan nilai rata-rata tersebut yang menjadi pembentuk kurva himpunan fuzzy awal dan nilai akhir kurva menggunakan kelipatan dari nilai rata-rata tersebut menjadi 7.720.000. Kemudian dibuatlah fungsi keanggotaan budget yang dipetakan ke dalam sepuluh himpunan fuzzy yaitu B1, B2, B3, B4, B5, B6, B7, B8, B9 atau B10 yang direpresentasikan pada Gambar 4.
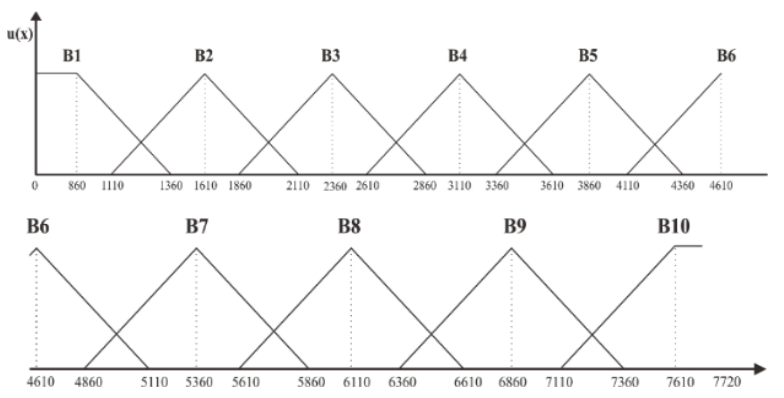

Gambar 4. Himpunan Fuzzy

Selain seperti pada tabel 1 yang merupakan distribusi frekuensi data budget dari 100 orang wisatawan, juga didapatkan data lainnya yang dibutuhkan untuk membuat fungsi keanggotaan penelitian ini, yaitu 
data lama wisata, akomodasi/hotel, makanan dan minuman, dan transportasi.

\section{b) Lama Wisata}

Berikut Fungsi keanggotaan lama wisata dipetakan ke dalam enam himpunan fuzzy yaitu H1, $\mathrm{H} 2, \mathrm{H} 3, \mathrm{H} 4, \mathrm{H} 5$, atau $\mathrm{H} 6$ yang direpresentasikan pada Gambar 5.

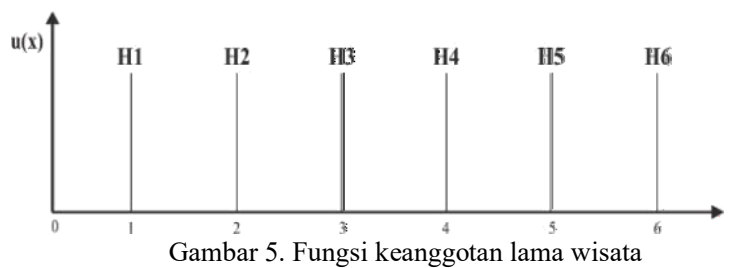

c) Akomodasi/hotel

Fungsi keanggotaan akomodasi/hotel dipetakan ke dalam tujuh himpunan fuzzy yaitu A1, A2, A3, A4, A5, A6 atau $\mathrm{H} 7$ yang direpresentasikan pada Gambar 6.

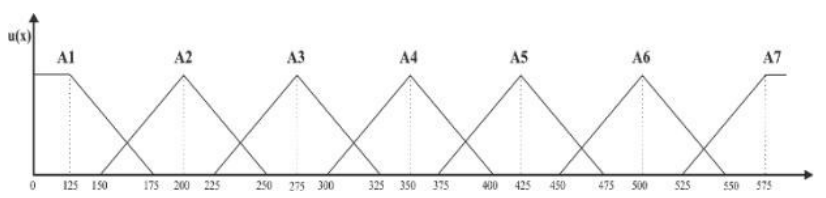

Gambar 6. Fungsi keanggotaan akomodasi/hotel

\section{d) Makanan dan minuman}

Fungsi keanggotaan makanan dan minuman dipetakkan ke dalam empat himpunan fuzzy yaitu M1, M2,M3, M4, M5, atau M6 yang direpresentasikan pada Gambar 7.

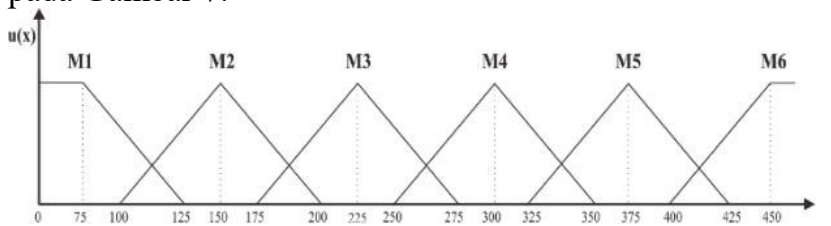

Gambar 7. Fungsi keanggotaan makanan dan minuman e) Transportasi

Fungsi keanggotaan transportasi dipetakan ke dalam empat himpunan fuzzy yaitu T1, T2, T3 atau T4 yang direpresentasikan pada Gambar 10.

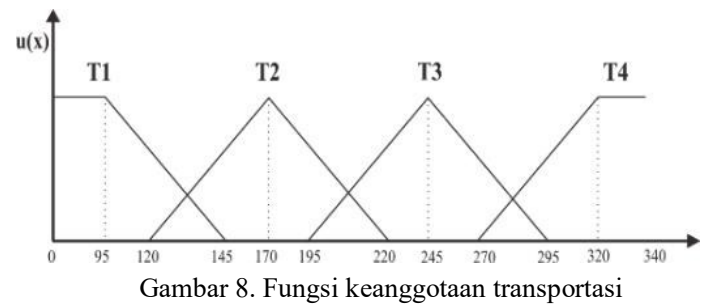

\section{f) Kesimpulan}

Fungsi keanggotaan kesimpulan memetakkan nilai fuzzy ke dalam tiga himpunan fuzzy yaitu Tidak, Cukup, atau Mungkin yang direpresentasikan pada Gambar 9.

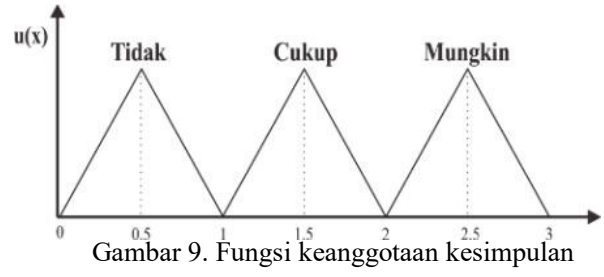

Berdasarkan kelima variabel yang digunakan yaitu budget, lama wisata, akomodasi/hotel, makanan dan minuman, serta transportasi maka jumlah aturan fuzzy yang dapat dibentuk adalah sebanyak $10 \times 6 \times 7$ x 6 x $4=10.080$ aturan/rule fuzzy. Tabel 2 merupakan aturan fuzzy yang terbentuk.

\begin{tabular}{lllllll}
\multicolumn{8}{c}{ Tabel 2. Aturan fuzzy } \\
\hline No & T & M & A & H & B & Kesimpulan \\
\hline 1 & T1 & M1 & A1 & H1 & B1 & MUNGKIN \\
2 & T1 & M1 & A1 & H1 & B2 & MUNGKIN \\
3 & T1 & M1 & A1 & H1 & B3 & MUNGKIN \\
$\cdot$ &. &. &. &. &. &. \\
. &. &. &. &. &. &. \\
6719 & T4 & M4 & A7 & H6 & B9 & TIDAK \\
6720 & T4 & M4 & A7 & H6 & B10 & TIDAK \\
\hline
\end{tabular}

Dalam menentukan variabel kesimpulan digunakan persamaan sebagai berikut :

$$
\mathbf{S B}=\mathbf{B}-(\mathrm{H} \times(\mathrm{A}+\mathrm{M}+\mathrm{T})
$$

\section{Keterangan :}

$\mathrm{T}=$ Transportasi

$\mathrm{M}=$ Makanan dan minuman

$\mathrm{A}=$ Akomodasi/hotel

$\mathrm{B}=$ Budget

$\mathrm{SB}=$ Sisa budget

$\mathrm{H}=$ Lama Wisata

Nilai tiap himpunan fuzzy ditentukan berdasarkan fungsi keanggotaan masing-masing variabel dengan mengambil nilai rata-rata tiap himpunan fuzzy. Contoh : T2 memiliki nilai 170.000 karena mengambil nilai himpunan T2 pada fungsi keanggotaan transportasi.

Berdasarkan Persamaan 1 maka aturan untuk menentukan himpunan kesimpulan adalah jika sisa budget $<$ Rp 100.000 maka "Tidak Memungkinkan", jika sisa budget Rp 100.000 - Rp 500.000 maka "Cukup Memungkinkan", dan jika > Rp. 500.000 maka kesimpulannya "Memungkinkan". Aturan tersebut ditentukan berdasarkan data pola sisa budget wisatawan pada Tabel 3 :

Tabel 3. Pola sisa budget wisatawan

\begin{tabular}{cccc}
\hline No & Range Sisa Budget & Frekuensi & $\mathbf{( \% )}$ \\
\hline 1 & $<\operatorname{Rp~100,000}$ & 0 & $0 \%$ \\
2 & Rp 100,000-Rp 500,000 & 56 & $56 \%$ \\
3 & $>$ Rp 500,000 & 44 & $44 \%$ \\
\hline & Total & 100 & $100 \%$ \\
\hline
\end{tabular}


Hasil perhitungan tahap fuzzifikasi sesuai dengan fungsi keanggotaan ditunjukkan pada Gambar 10 dengan skenario perhitungan hasil pertimbangan wisata yang digunakan sesuai dengan section VA.

\begin{tabular}{|c|c|c|}
\hline Himpunan Fuzzy Budget & Himpunan Fuzzy Lama Wisata & Himpunan Fuzzy Hote1/Akomodasi \\
\hline$B 1=0.0$ & $\mathrm{H} 1=0.0$ & $\lambda_{1}=0.0$ \\
\hline $82=0.92$ & $\mathrm{H}_{2}=0.0$ & $\mathrm{~A}_{2}=0.63$ \\
\hline$B 3=0.0$ & вз $=1.0$ & $A_{3}=0.0$ \\
\hline $84=0.0$ & $\mathrm{H} 4=0.0$ & $\lambda 4=0.0$ \\
\hline $\mathrm{B} 5=0.0$ & H5 $=0.0$ & $25=0.0$ \\
\hline $86=0.0$ & H6 $=0.0$ & $\lambda=0.0$ \\
\hline $87=0.0$ & Himpunan Fuzzy Makanan/Minuman, & A $7=0.0$ \\
\hline $88=0.0$ & $\mathrm{M1}=0.3$ & Himpunan Fuzzy Transportasi \\
\hline$B 9=0.0$ & $M_{2}=0.2$ & $\mathrm{TI}=0.0$ \\
\hline \multirow[t]{4}{*}{$810=0.0$} & ма $=0.0$ & $T_{2}=0.51$ \\
\hline & $\mathrm{M}=0.0$ & $\mathrm{~T} 3=0.0$ \\
\hline & $\mathrm{M} 5=0.0$ & $\mathrm{~T} 4=0.0$ \\
\hline & $M 6=0.0$ & \\
\hline
\end{tabular}

Gambar 10. Hasil fuzzifikasi

\subsubsection{Implikasi}

Implikasi adalah proses penarikan kesimpulan dari IF-THEN rule dengan menggunakan fungsi MIN dari aturan yang terbentuk. Gambar 11 merupakan hasil proses implikasi :

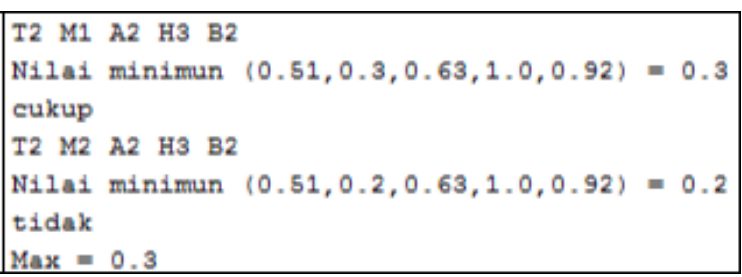

Gambar 11. Hasil proses implikasi

\subsubsection{Agregasi/komposisi aturan}

Agregasi adalah proses mengombinasikan semua keluaran IF-THEN rule jika terdapat hasil keluaran yang lebih dari satu pada proses implikasi, komposisi aturan/agregasi menggunakan fungsi MAX. Berdasarkan Gambar 13, terdapat 2 hasil implikasi yaitu 0.3 dan 0.2 . Dengan proses agregasi maka :

$$
\begin{aligned}
\mu \operatorname{Maks}(\mathrm{x}) & =\operatorname{Max}(\alpha 1 ; \alpha 2) \\
& =\operatorname{Max}(0,3 ; 0,2) \\
= & 0,3(\text { Cukup Memungkinkan })
\end{aligned}
$$

\subsubsection{Defuzzifikasi}

Model defuzzifikasi yang digunakan dalam menentukan pertimbangan berwisata di Pulau Lombok adalah Mean of Maxima (MOM), berikut perhitungan defuzzifikasi :

$$
\begin{array}{rlrl}
\mu \operatorname{Maks}(\mathrm{x}) & =0,3 & & \\
-\alpha_{\operatorname{Max}} & =\mathrm{x} 1-1 / 0.5 & -\alpha_{\operatorname{Max}} & =2-\mathrm{x} 2 / 0.5 \\
0,3 & =\mathrm{x} 1-1 / 0.5 & 0,3 & =2-\mathrm{x} 2 / 0.5 \\
0.15 & =\mathrm{x} 1-1 & 0.15 & =2-\mathrm{z} 2 \\
\mathbf{x 1} & =\mathbf{1 . 1 5} & \mathbf{z 2} & =\mathbf{1 . 8 5} \\
-\mathrm{xAkhir}=\frac{x 1+x 2}{2}=\frac{1.15+1.185}{2}=\frac{3}{2} & =\mathbf{1 . 5}
\end{array}
$$

Dari hasil perhitungan defuzzifikasi di atas, didapatkan nilai fuzzy 1.5 yang berarti menghasilkan keluaran "Cukup Memungkinkan" karena berada pada rentang 1-2 sesuai dengan himpunan fuzzy kesimpulan pada Gambar 9.

\subsection{Algoritma Genetika}

Algoritma Genetika sebagai cabang dari algortima evolusi merupakan metode adaptive yang bisa digunakan untuk memecahkan suatu pencarian nilai dalam sebuah masalah optimasi. Dengan meniru teori evolusi, algoritma genetika dapat digunakan untuk mencari solusi permasalahan-permasalahan dalam dunia nyata (Meutia, 2017). Gambar 12 menunjukkan tahapan umum pada Algoritma Genetika.

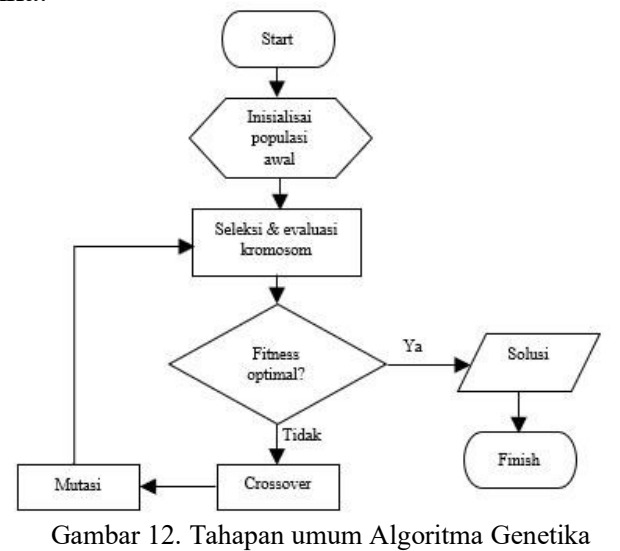

Gambar 12 menunjukkan Algoritma Genetika memiliki 4 tahapan umum dalam menentukan solusi optimum yaitu inisiasi populasi awal, seleksi dan evaluasi kromosom, crossover, dan mutasi. Inisiasi populasi awal dilakukan dengan memberikan nilai acak untuk tiap gen pada masing-masing kromosom, sehingga populasi yang terbentuk akan merepresentasikan solusi awal untuk sebuah permasalahan. Tahap kedua melakukan seleksi dan populasi kromosom untuk menentukan kromosom dengan fitness terbaik dan memberikan kesempatan pada kromosom dengan fitness terbaik melakukan reproduksi lebih banyak. Jika fitness optimal belum ditemukan maka selanjutnya dilakukan proses crossover yaitu persilangan antara kromosomkromosom induk dan proses mutasi yang melakukan pergantian sebuah atau beberapa gen pada sebuah kromosom. Proses-proses tersebut terus dilakukan hingga ditemukannya kromosom dengan nilai fitness paling optimal.

Pada penelitian ini, setelah melakukan penentuan pertimbangan berwisata di Pulau Lombok dengan fuzzy Mamdani, jika aplikasi memberikan kesimpulan wisata cukup atau memungkinkan maka aplikasi akan memberikan alokasi penggunaan budget yang optimal dengan metode Algoritma Genetika. Persamaan berikut yang akan digunakan dalam mencari alokasi penggunaan budget optimal :

$$
B=\mathrm{H} \times(\mathrm{A}+\mathrm{M}+\mathrm{T}))
$$

Dari Persamaan 2, representasi kromosom yang akan terbentuk adalah variabel makanan dan minuman, akomodasi/hotel, dan transportasi menjadi 
gen-gen penyusun tiap kromosom seperti persamaan 3 .

Kromosom[i] = [Makanan; Hotel; Transportasi $]$ (3)

\subsubsection{Inisiasi populasi awal}

Sebelum melakukan proses inisiasi populasi awal, terlebih dahulu dilakukan penentuan batasan untuk tiap variabel. Penentuan batasan dilakukan dengan hasil perkalian dari lama wisata dengan jumlah ketiga variabel tersebut harus memiliki hasil lebih besar dari budget yaitu Rp. 1.650.000. Jika hasil yang didapatkan kurang dari budget, maka tiap variabel ditambahkan Rp 50.000 sesuai dengan rentang titik fungsi keanggotaan tiap variabel sampai nilainya lebih besar dari budget. Dari skenario pengujian sesuai dengan section VA didapatkan nilai batasan untuk hotel Rp 181.000 - Rp. 231.000, untuk makanan dan minuman Rp 165.000 - Rp 240.000, dan untuk transportasi Rp 145.000 - Rp 195.000.

Gambar 13 menunjukkan hasil inisiasi populasi awal setelah nilai batasan tiap variabel didapatkan :

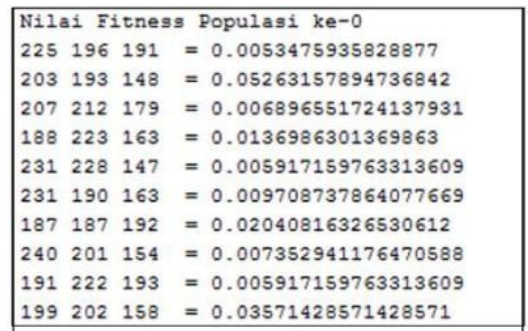

Gambar 13. Populasi awal

\subsubsection{Evaluasi dan Seleksi Kromosom}

Evaluasi dan seleksi kromosom bertujuan untuk mendapatkan kromosom/individu terbaik dalam sebuah populasi dan memberikan kromosom dengan nilai fitness terbaik tersebut memiliki kesempatan untuk bereproduksi lebih banyak.

Gambar 14 merupakan diagram alir dari tahap evaluasi dan seleksi kromosom dengan menghitung fitness dan melakukan seleksi roulette wheel :

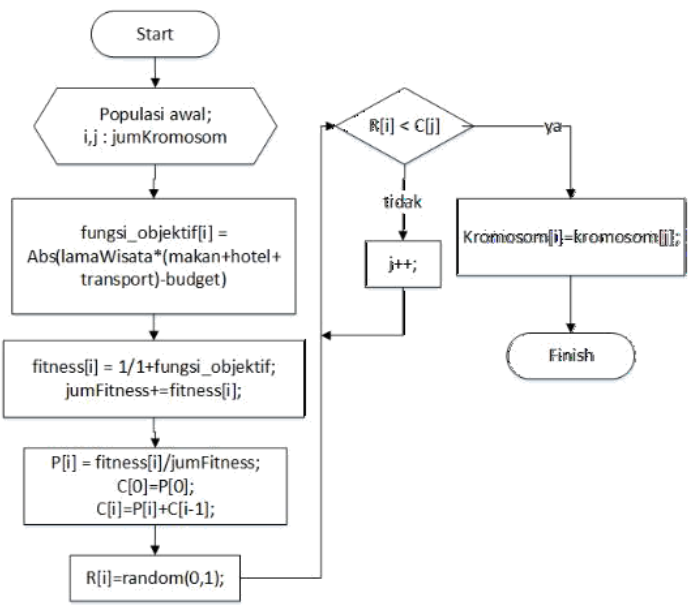

Gambar 14. Algoritma evaluasi dan seleksi kromosom

\subsubsection{Crossover}

Crossover merupakan persilangan antar dua kromosom induk untuk menghasilkan kromosom baru yang identik dengan induknya. Gambar 15 merupakan diagram alir dalam tahap crossover.

Gambar 16 menunjukkan kromosom optimal didapatkan pada generasi/populasi ke-8 di kromosom ke-4 setelah melalui proses evaluasi, seleksi, crossover, dan mutasi. nilai fitness optimal didapatkan pada populasi ke-8 di kromosom ke-4 dengan nilai alokasi penggunaan budget yaitu, untuk makanan/minuman Rp 209.000, untuk akomodasi/hotel Rp 193.000, dan untuk transportasi Rp 148.000.

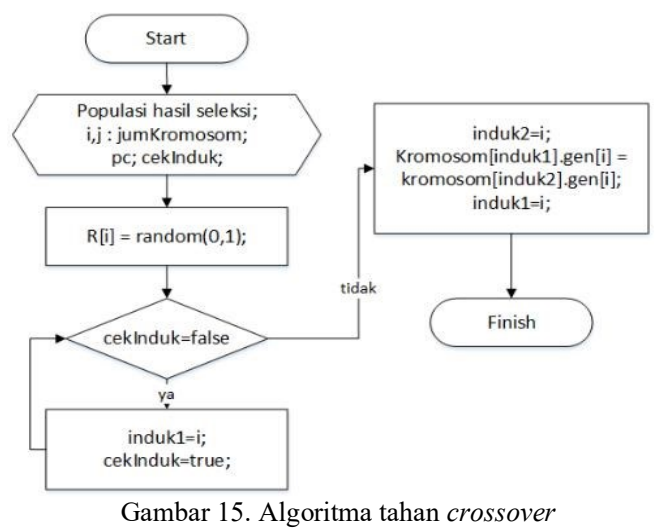

\subsubsection{Mutasi}

Gambar 16 merupakan diagram alir dalam tahapan mutasi.

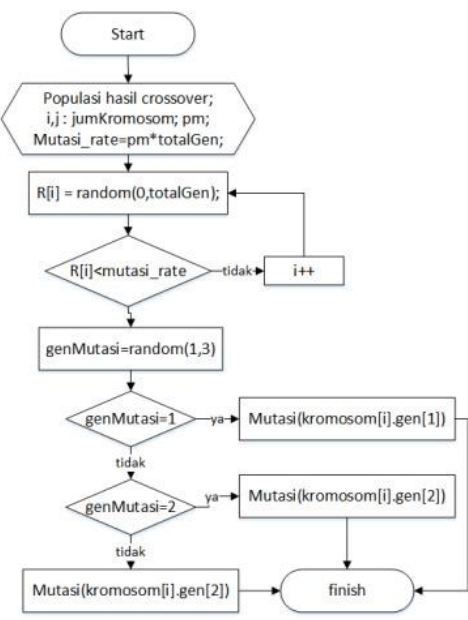

Gambar 16. Algoritma tahap mutasi

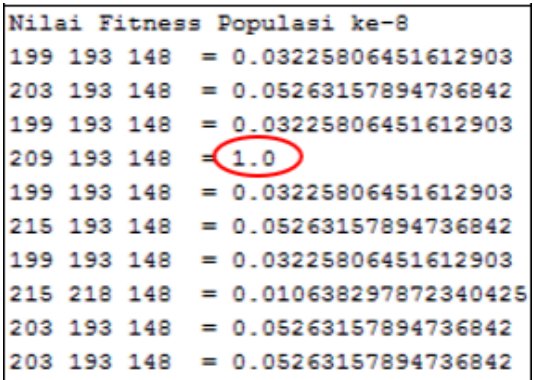

Gambar 17. Populasi terbaik 


\section{HASIL DAN PEMBAHASAN}

Bagian ini membahas hasil pengujian aplikasi yang menggunakan Logika Fuzzy Mamdani untuk memberikan pertimbangan wisata di Lombok dan Algoritma Genetika dalam memberikan saran alokasi penggunaan budget yang optimal.

\subsection{Fuzzy Mamdani}

Pengujian dilakukan untuk mengetahui model fuzzy yang digunakan sesuai dengan hasil perhitungan manual \& untuk mengetahui apakah model defuzzifikasi yaitu model Mean of Max (MOM) sesuai dengan model defuzzifikasi Centroid \& Bisector. Tabel 4 menunjukkan skenario pengujian

Tabel 4. Skenario pengujian aplikasi (satuan 1000).

\begin{tabular}{|c|c|c|c|c|c|}
\hline No & Budget & Hari & Hotel & Makan & Transport \\
\hline 1 & 3,300 & 5 & 155 & 135 & 150 \\
\hline 2 & 1,850 & 3 & 100 & 100 & 140 \\
\hline 3 & 3,000 & 4 & 200 & 200 & 150 \\
\hline 4 & 5,250 & 4 & 525 & 525 & 157.5 \\
\hline 5 & 2,350 & 3 & 250 & 250 & 100 \\
\hline 6 & 2,475 & 3 & 170 & 495 & 247.5 \\
\hline 7 & 2,500 & 6 & 100 & 120 & 90 \\
\hline 8 & 1,650 & 3 & 181.5 & 110 & 165 \\
\hline 9 & 1,485 & 2 & 297 & 165 & 165 \\
\hline 10 & 3,000 & 3 & 412 & 550 & 302.5 \\
\hline 11 & 1,155 & 2 & 100 & 100 & 115.5 \\
\hline 12 & 1,815 & 4 & 110 & 214.5 & 110 \\
\hline 13 & 1,650 & 3 & 100 & 137 & 165 \\
\hline 14 & 2,500 & 3 & 250 & 166 & 200 \\
\hline 15 & 3,000 & 5 & 200 & 150 & 150 \\
\hline 16 & 4,350 & 4 & 326.3 & 435 & 290 \\
\hline 17 & 2,200 & 1 & 1,000 & 1,000 & 100 \\
\hline 18 & 2,300 & 4 & 250 & 200 & 105 \\
\hline 19 & 2,475 & 3 & 330 & 110 & 150 \\
\hline 20 & 5,500 & 4 & 625 & 375 & 200 \\
\hline
\end{tabular}

Tabel 5 menunjukkan hasil pengujian aplikasi dengan perhitungan manual.

Tabel 5. Pengujian Fuzzy Mamdani dengan perhitungan manual

\begin{tabular}{cccc}
\hline No & Fuzzy Mamdani & Manual & Keterangan \\
\hline 1 & Memungkinkan & Memungkinkan & Sesuai \\
2 & Memungkinkan & Memungkinkan & Sesuai \\
3 & Memungkinkan & Memungkinkan & Sesuai \\
4 & Memungkinkan & Memungkinkan & Sesuai \\
5 & Memungkinkan & Memungkinkan & Sesuai \\
6 & Tidak & Tidak & Sesuai \\
7 & Memungkinkan & Memungkinkan & Sesuai \\
8 & Memungkinkan & Memungkinkan & Sesuai \\
9 & Memungkinkan & Memungkinkan & Sesuai \\
10 & Tidak & Tidak & Sesuai \\
11 & Memungkinkan & Memungkinkan & Sesuai \\
12 & Tidak & Tidak & Sesuai \\
13 & Memungkinkan & Memungkinkan & Sesuai \\
14 & Memungkinkan & Memungkinkan & Sesuai \\
15 & Memungkinkan & Memungkinkan & Sesuai \\
16 & Memungkinkan & Memungkinkan & Sesuai \\
17 & Memungkinkan & Memungkinkan & Sesuai \\
18 & Tidak & Tidak & Sesuai \\
\hline
\end{tabular}

\begin{tabular}{cccc}
\hline No & Fuzzy Mamdani & Manual & Keterangan \\
\hline 19 & Memungkinkan & Memungkinkan & Sesuai \\
20 & Memungkinkan & Memungkinkan & Sesuai \\
\hline
\end{tabular}

Berdasarkan Tabel 5, disimpulkan bahwa hasil perhitungan manual memiliki keluaran yang sama dengan aplikasi menggunakan Logika Fuzzy Mamdani dengan model defuzzifikasi Mean of Max (MOM).

Tabel 6 menunjukkan hasil aplikasi dengan model defuzzifikasi Centroid, selain itu juga dilakukan model defuzzifikasi dengan Bisector.

\begin{tabular}{|c|c|c|c|c|}
\hline \multirow{2}{*}{ No } & \multicolumn{2}{|r|}{ MOM } & \multicolumn{2}{|r|}{ Centroid } \\
\hline & NF & Kesimpulan & NF & Kesimpulan \\
\hline 1 & 2.5 & Memungkinkan & 2.5 & Memungkinkan \\
\hline 2 & 1.5 & Cukup & 1.73 & Cukup \\
\hline 3 & 2.5 & Memungkinkan & 2.5 & Memungkinkan \\
\hline 4 & 2.5 & Memungkinkan & 2.5 & Memungkinkan \\
\hline 5 & 2.5 & Memungkinkan & 2.5 & Memungkinkan \\
\hline 6 & 0.5 & Tidak & 0.5 & Tidak \\
\hline 7 & 1.5 & Cukup & 1.73 & Cukup \\
\hline 8 & 1.5 & Cukup & 1.09 & Cukup \\
\hline 9 & 1.5 & Cukup & 1.5 & Cukup \\
\hline 10 & 0.5 & Tidak & 0.5 & Tidak \\
\hline 11 & 2.5 & Memungkinkan & 2.5 & Memungkinkan \\
\hline 12 & 0.5 & Tidak & 0.5 & Tidak \\
\hline 13 & 1.5 & Cukup & 1.5 & Cukup \\
\hline 14 & 2.5 & Memungkinkan & 2.27 & Memungkinkan \\
\hline 15 & 2.5 & Memungkinkan & 2.5 & Memungkinkan \\
\hline 16 & 1.5 & Cukup & 1.35 & Cukup \\
\hline 17 & 2.5 & Memungkinkan & 2.5 & Memungkinkan \\
\hline 18 & 0.5 & Tidak & 0.5 & Tidak \\
\hline 19 & 2.5 & Memungkinkan & 2.09 & Memungkinkan \\
\hline 20 & 2.5 & Memungkinkan & 2.5 & Memungkinkan \\
\hline
\end{tabular}

Keterangan : NF = Nilai Fuzzy

Hasil Pengujian yang ditunjukkan pada Tabel 6, hasil defuzzifikasi pada kasus ini dengan menggunakan model defuzzifikasi Centroid, dan Bisector, serta MOM, dapat disimpulkan bahwa mereka memiliki hasil yang sama meskipun terdapat nilai keluaran Fuzzy yang berbeda pada beberapa skenario pengujian. Perbedaan nilai fuzzy tersebut tidak mempengaruhi hasil kesimpulan karena nilai fuzzy yang dihasilkan pada defuzzifikasi MOM, Centroid, dan Bisector masih berada pada rentang kesimpulan pertimbangan wisata yang sama seperti ditunjukkan pada Gambar 9.

Seperti pada Tabel 6, skenario pengujian nomor 2 dengan model defuzzifikasi MOM menghasilkan nilai fuzzy 1.5 dengan kesimpulan "Cukup Memungkinkan”, sedangkan model Centroid menghasilkan nilai fuzzy 1.73 dengan kesimpulan "Cukup Memungkinkan" juga. Meskipun nilai fuzzy yang dihasilkan berbeda dari kedua model defuzzifikasi tersebut, kesimpulan yang diberikan sama karena masih berada pada rentang 1.1-2.0 untuk jenis kesimpulan "Cukup Memungkinkan" sesuai 
dengan fungsi keanggotaan kesimpulan pada Gambar 9.

\subsection{Algoritma Genetika}

Pengujian dilakukan untuk mengetahui solusi optimum dalam memberikan alokasi penggunaan budget optimal terhadap skenario pengujian pada section VA. Pengujian ini juga diharapkan mampu mengetahui pengaruh kombinasi nilai probabilitas crossover (pc) dan probabilitas mutasi $(\mathrm{pm})$ dalam memberikan solusi yang optimal. Hasil pengujian akan ditampilkan dalam bentuk grafik yang dihasilkan dari setiap kombinasi probabilitas crossover $(\mathrm{pc})$ dan probabilitas mutasi $(\mathrm{pm})$, nilai pc yang digunakan antara $0.3-0.8$ dan nilai pm kurang dari 0.5 (Mahmudy, 2014).

Dalam menentukan kombinasi terbaik dari variabel pc dan pm dengan skenario yang diberikan, digunakanlah variabel waktu eksekusi (t) dengan jumlah generasi (i) hingga nilai fitness optimal ditemukan sesuai dengan Persamaan 4.

$$
\text { solusi optimum }=\frac{\text { Jumlah iterasi }(i)}{\text { waktu iterasi }(t)}
$$

Persamaan 4 digunakan jika solusi optimal didapatkan pada nilai iterasi/jumlah generasi yang sama, untuk nilai iterasi/jumlah generasi yang berbeda ditentukan berdasarkan iterasi/jumlah generasi (i) karena nilai iterasi (i) berbanding lurus dengan nilai waktu eksekusi (t). Artinya semakin besar nilai iterasi (i) maka semakin besar waktu eksekusinya (t), sehingga nilai (i) terkecil merupakan solusi optimum (hasil kombinasi terbaik). Gambar 17 menunjukkan hasil dari proses kombinasi nilai pc dan pm sesuai dengan skenario pengujian yang diberikan.

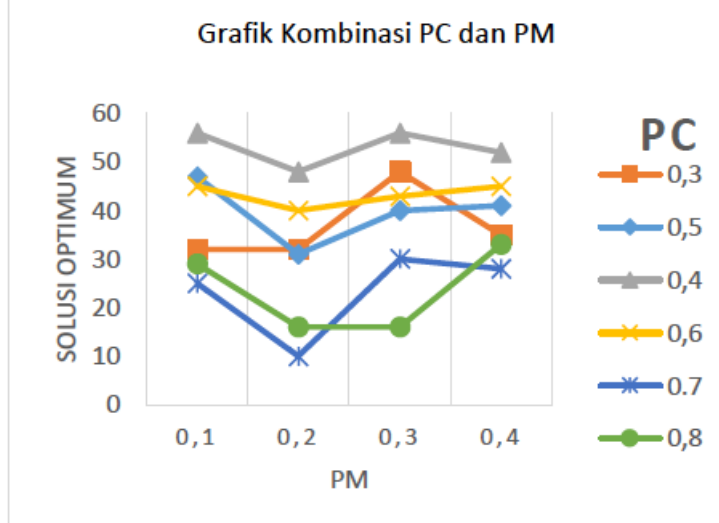

Gambar 17. Grafik kombinasi pc dan pm

Berdasarkan grafik pada Gambar 17 tersebut, nilai solusi optimum dengan nilai probabilitas mutasi $(\mathrm{pm})=0.2$ dengan kombinasi nilai probabilitas crossover (pc) antara $0.3-0.8$ menghasilkan nilai solusi optimum yang relatif lebih kecil. Hal itu terlihat dari nilai rata-rata yang dihasilkan yaitu 30 dari seluruh kombinasi probabilitas mutasi (pm) terhadap probabilitas crossover (pc) yang lebih kecil dibandingkan nilai probabilitas mutasi (pm) lainnya. Nilai solusi optimum terbaik juga diperoleh pada nilai probabilitas mutasi (pm) 0.2 dengan nilai probabilitas crossover $(\mathrm{pc})=0.7$, dapat dilihat pada Gambar 17 yang menghasilkan nilai optimum 10 .

\subsection{Screenshot Aplikasi}

Gambar 18 - 21 menunjukkan screenshoot fiturfitur pada aplikasi Pertimbangan Wisata di Pulau Lombok dengan Metode Fuzzy Mamdani dan Algoritma Genetika.
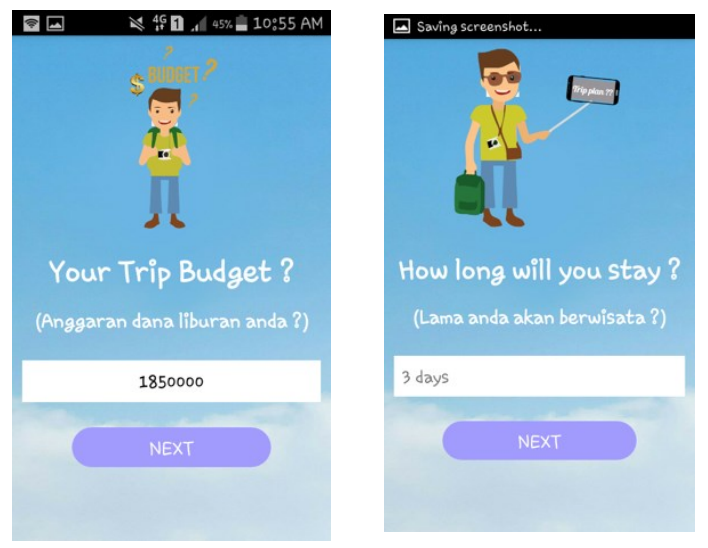

Gambar 18. Tampilan input-an budget dan lama wisata
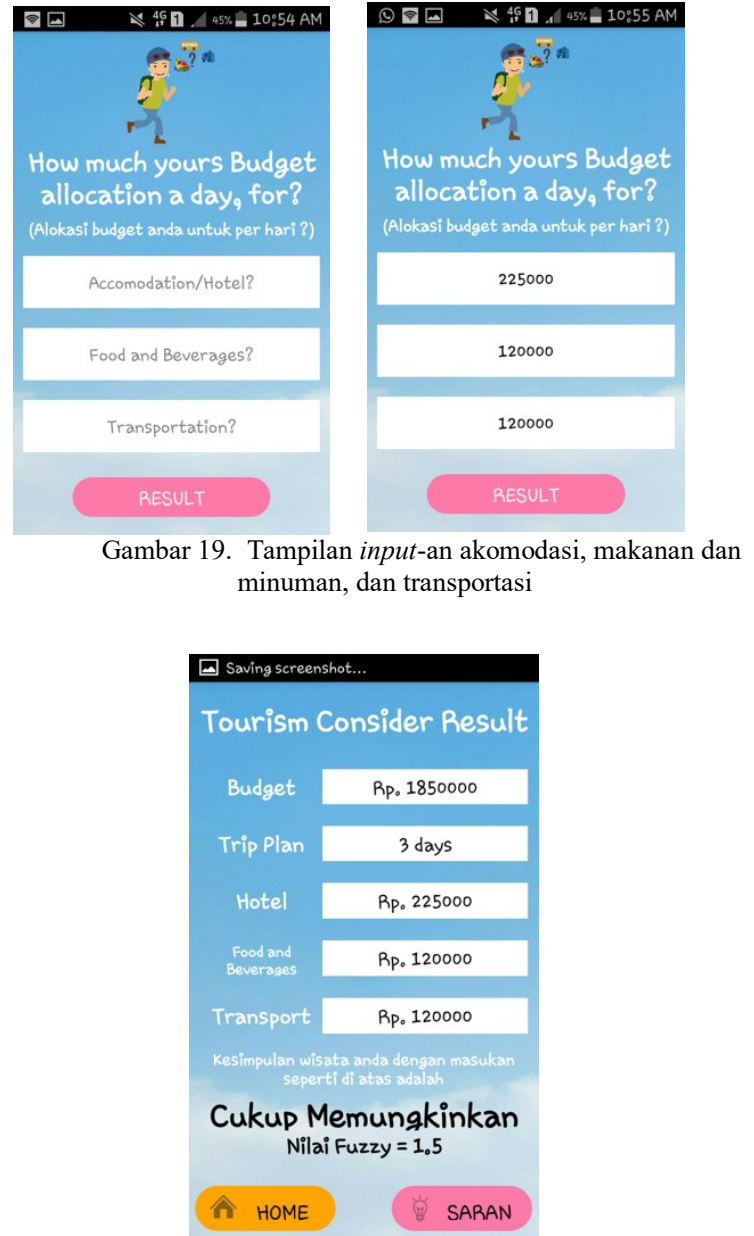


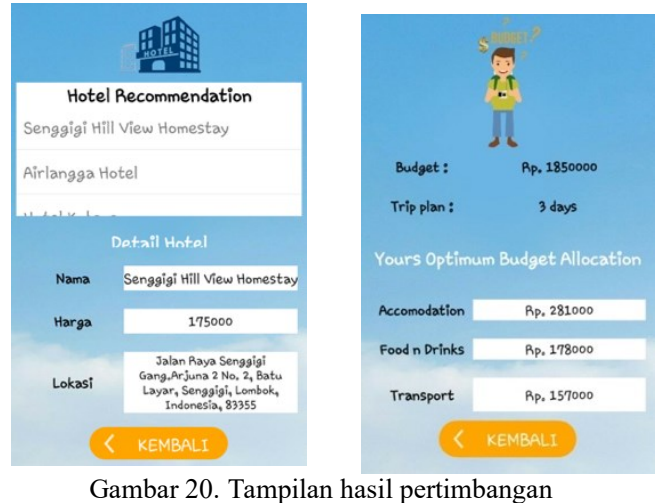

Gambar 21. Tampilan saran hotel dan alokasi budget

\section{KESIMPULAN}

Hasil pengujian aplikasi dalam memberikan rekomendasi/pertimbangan wisata menggunakan Logika Fuzzy Mamdani dengan perhitungan manual menghasilkan keluaran yang sama dalam 20 kasus/skenario pengujian. Selain itu hasil pengujian aplikasi dalam memberikan pertimbangan wisata menggunakan Logika Fuzzy Mamdani pada model defuzzifikasi Mean of Max (MOM) dengan model defuzzifikasi Centroid dan Bisector mengasilkan keluaran/pertimbangan wisata yang sama. Beberapa skenario pengujian menggunakan model defuzzifikasi MOM, Centroid, dan Bisector menghasilkan nilai fuzzy yang berbeda, namun perbedaan tersebut masih dalam satu rentang himpunan fuzzy pada fungsi keanggotaan kesimpulan, sehingga keluaran yang dihasilkan tetap sama. Kemudian nilai kombinasi dari variabel probabilitas crossover (pc) dan probabilitas mutasi berpengaruh untuk menentukan nilai fitness dalam memberikan saran penggunaan alokasi budget yang optimal. Kombinasi nilai probabilitas crossover (pc) dan probabilitas mutasi (pm) yang paling optimun didapatkan pada kombinasi nilai $\mathrm{pc}=0.7$ dan nilai $\mathrm{pm}$ $=0.2$. Dalam skenario pengujian yang telah diberikan, kombinasi tersebut mendapatkan fitness terbaik pada generasi ke-10.

Saran untuk penelitian selanjutnya pada penerapan Logika Fuzzy, fungsi keanggotaan setiap variabel dibuat dengan menggunakan sebuah metode pendukung untuk mendapatkan fungsi keanggotaan yang lebih optimal. Selain itu, sistem yang telah dibuat diharapkan mampu dikembangkan ke dalam sebuah aplikasi yang lebih kompleks sesuai kebutuhan wisatawan.

\section{DAFTAR PUSTAKA}

ARIFIN, Saiful. 2015. Implementasi Logika Fuzzy Mamdani untuk Mendeteksi Kerentanan Daerah Banjir di Semarang Utara. Skripsi. Semarang. Jurusan Matematika, FMIPA, Universitas Semarang.

ARINANTA, Firmanda R. 2017. Penerapan Logika Fuzzy dengan Metode Logika Fuzzy
Tsukamoto dalam menentukan Pertimbangan Berwisata di Pulau Lombok. Skripsi. Mataram. Program Studi Teknik Informatika, Fakultas Teknik, Universitas Mataram.

AYUNINGTIAS Laras P, Irfan M, dan Jumaidi. 2017. Analisa Perbandingan Logic Fuzzy metode Tsukamoto, Sugeno, dan Mamdani (Studi Kasus: Prediksi Jumlah Pendaftaran Mahasiswa Baru Fakultas Sains dan Teknologi UIN Sunan Gunung Djati Bandung). Bandung. Jurusan Teknik Informatika, Fakultas Sains dan Teknologi, Universitas Islam Negeri Sunan Gunung Jati Bandung.

ISMAYA, Ulvi. 2016. Penerapan Logika Fuzzy Mamdani untuk Prediksi Jumlah Produksi Tahu. Skripsi. Yogyakarta. Program Studi Teknik Informatika, Fakultas Sains dan Teknologi, Universitas Islam Negeri Sunan Kalijaga.

MAHMUDY, W.F. 2014. Algoritma Evolusi. PTIIK : Universitas Brawijaya

MASLIM, Martinus. 2013. Aplikasi Logika fuzzy pada Sistem pakar Pariwisata. Seminar Nasional TIK 2013. Yogyakarta. PS Teknik Informatika, Fakultas Teknologi Industri, Universitas Atma Jaya Yogyakarta.

MEUTIA, Nur Shabrina. 2017. Penjadwalan Mata Kuliah Menggunakan Metode Algortima Genetika. Skripsi. PS Teknik Informatika, Fakultas Teknik, Universitas Mataram.

SOLIKIN, Fajar. 2011. Aplikasi Logika Fuzzy dalam Optimasi Produk banrang Menggunakan Metode Mamdani dan Metode Sugeno. PS Matematika, Jurusan Pendidikan Matematika, FMIPA, Universitas Negeri yogyakarta.

SUKANDY Dwi Martha, Basuki Agung $\mathrm{T}$, dan Pusoasari Shinta. 2014. Penerapan Metode Fuzzy Mamdani untuk Memprediksi Jumlah Produksi Minyak Sawit Berdasarkan Data Persediaan dan Jumlah Permintaan (Studi Kasus PT Perkebunan Mitra Ogan Baturaja). Program Studi Teknik Informatika, STMIK GI MDP.

SUKATON, Rama M. 2011. Penggunaan Algoritma Genetika dalam Masalah jalur Terpendek Pada jaringan Data. Skripsi. Depok. FMIPA, Program Studi Sarjana Matematika, Universitas Indonesia.

WIDODO Agus Wahyudi dan Nahnudy Wayan Firdaus. 2010. Penerapan Algoritma Genetika pada Sistem Rekomendasi Wisata Kuliner. Malang. Program Studi Ilmu Komputer, Jurusan Matematika, FMIPA, Universitas Brawijaya. 